\title{
Russian Culture in Manchuria and the Memoirs of Valery Pereleshin ${ }^{1}$
}

$\mathcal{W}$ hen Anton Chekhov sailed eastward by riverboat on the Amur during his trip to Sakhalin (Amur then marked, as it still does, the border between China and Siberia), he was struck by the abundant wildlife and sparse population. In his letter to Aleksei Suvorin, 27 June 1890, he wrote: "Cliffs, crags, forests, thousands of ducks, herons and all sorts of long-beaked rascals, and utter wilderness. The Russian bank is on the left, the Chinese on the right. If I feel like it, I can look at Russia, and if I feel like it, I can look at China. China is as barren and savage as Russia: villages and sentinel huts are few and far between." Even though China had been ruled for centuries by Manchu emperors, the homeland of that dynasty, Manchuria, was a vast nature preserve with far fewer towns and villages than the area could accommodate.

In 1896 the Russian government obtained permission from the Chinese to construct, through Manchuria, a continuation of the TransSiberian Railroad to Vladivostok. This was the Chinese Eastern Railway. A bit later, a southern branch was constructed toward the Russian towns of Dalny (Дальний; Dairen after the Russo-Japanese War, now Dalian in China) and Port Arthur, on the Liaotung peninsula by the Yellow Sea. Because of all this vast railroad construction, thousands of people of various nationalities who inhabited the Russian Empire moved to Manchuria. In 1898 a settlement was founded at the point of intersection of the eastern railroad branch and the wide river Sungari, a tributary of the Amur. ${ }^{3}$

1 Review of Russian Poetry and Literary Life in Harbin and Shanghai, 1830-1850: The Memoirs of Valerij Perelešin, ed. Jan Paul Hinrichs (Amsterdam: Rodopi, 1987). Originally published as "Memoirs of Harbin" in Slavic Review 48, no. 2 (Summer 1989): 284-90.

2 Anton Chekhov's Life and Thought: Selected Letters and Commentary, trans. Michael Henry Heim, ed. Simon Karlinsky (Berkeley: University of California Press, 1973), 167.

3 A detailed account of Russian railroad construction in Manchuria during the 1890s and of the foundation of Harbin is contained in E. Kh. (Evgenii Khrisanfovich) Nilus, Istoricheskii obzor kitaiskoi vostochnoi zheleznoi dorogi, 1896-1923 gg. (Harbin, 1923), vol. 1. Nilus was married to the poet Aleksandra Parkau. 
Initially named the Sungari Settlement, the new town soon became Harbin, a distorted name of a Chinese fishing hamlet later absorbed by the town. Arseny Nesmelov, the foremost Harbin poet of the 1920s and 1930s, depicted the founders and planners of Harbin in one of his poems: "Inzhener. Rasstegnut vorot. / Fliaga. Karabin. / -Zdes' postroim russkii gorod, / Nazovem-Harbin." ${ }^{\prime}$ Nesmelov wondered whether the whole project might be a belated manifestation of the ferment inherited from Peter the Great. Indeed, Harbin was a boomtown, comparable in the speed of its growth to St. Petersburg (but without the attendant cruelty) or to San Francisco during the Gold Rush. Within five years there were Russian hotels, schools, churches, and theaters. The Russo-Japanese War, which Russia lost, enriched Harbin. It became the rest and recuperation place for Russian officers and soldiers. Many of these men were so impressed by the opportunities for jobs, the inexpensive way of life, and the seeming absence of national or racial animosities that they resolved to move to Harbin after demobilization. Both sets of the present reviewer's grandparents moved to Manchuria at the urging of their sons who had served there as soldiers during the war of 1904-6.

Several misunderstandings about the Russian presence in Harbin ought to be cleared up before addressing the volume under review. It was not primarily a city of refugees, as the back cover of the book implies. It is true that the Russian-speaking population, which included large contingents of Ukrainians, Jews, Poles, Georgians, and Tatars, rose to some 127,000 after the October Revolution. This figure includes only those who stayed. Uncounted thousands made brief stops in Harbin on their way to other cities in China or to other countries. Unlike the Russian émigrés who went to Paris or Prague or even to Shanghai, the new residents of Harbin were not a minority surrounded by a foreign population. They found themselves instead in an almost totally Russian city, populated mainly by people with roots in the south of European Russia. Speakers of Russian who grew up in Harbin and later moved to the Soviet Union or the United States were often surprised to learn that they spoke the dialects of Kharkov or Odessa.

4 “An engineer. Collar open / A canteen. A carbine. / - Here we'll build a Russian city. / We'll call it-Harbin."-Ed. 
On this one point Jan Paul Hinrichs is mistaken in his otherwise excellent introduction to the memoirs of the Harbin poet Valery Pereleshin: Harbin did not look like "any provincial Siberian city," because many of its buildings, boulevards, and parks were planned-well before the October Revolution-by distinguished Russian architects and also by Swiss and Italian town planners (I found the models for Harbin's Municipal Garden in Switzerland and the north of Germany, rather than anywhere in the Soviet Union). Nor was Harbin "a lifelike reconstruction of prerevolutionary Russia on Chinese soil"- - it had been a Russian city all along, one that had escaped the Revolution, the civil war, and Stalin's collectivization and had managed to keep well into the 1940s the high standard of living that typified Russia during the decade that preceded World War I. ${ }^{5}$

5 The economic prosperity of Russian Harbin in the second, third, and fourth decades of the twentieth century was interconnected with the economic boom in the rest of Manchuria, occasioned by the mass influx of Chinese farmers, fur trappers, and tradesmen. This led to a great demand for American-made agricultural machines and implements, which were distributed by several firms based in Harbin. Manchurian soybean products, animal skins, lumber, and other commodities were also exported to Germany and other European countries. See Frederick Simpich, "Manchuria, Promised Land of Asia: Invaded by Millions of Settlers, This Vast Region Now Recalls Early Boom Days of the American West," National Geographic Magazine, October 1929, 379-428; and Owen Lattimore, "Byroads and Backwoods of Manchuria: Where Violent Contrasts of Modernism and Unaltered Ancient Tradition Clash," ibid., January 1932, 101-30. There were, as other commentators have pointed out, Russian beggars, prostitutes, and drug addicts in Harbin, but these were very small minorities.

Transient foreign visitors, who often assumed that the entire Russian-speaking population of Harbin had recently escaped from the Soviet Union, were hard put to explain the prosperous appearance of the street crowds. Jan Paul Hinrichs cites a long excerpt from Harry A. Franck's book Wandering in Northern China (New York, 1923). Franck wrote that the "ladies as well gowned as at the Paris races [who] strolled with men faultlessly garbed by European standards" all had "not a crust left at home" and sold their "necessary things" to achieve this deceptive appearance.

Lilian Grosvenor Coville ("Here in Manchuria. Many Thousand Lives Were Lost and More Than Half the Crops Destroyed by the Floods of 1932." National Geographic Magazine, February 1933, 233-56) visited Harbin in the fateful year that brought a major flood, the Japanese invasion, and an epidemic of cholera. She, too, was puzzled by the well-dressed look of Harbin Russians. She accepted the explanation that Harbin women were divided into two classes: the attractive ones, who were all cabaret hostesses, and the unattractive ones, who were all dentists. As to the men, they were either supported by their dentist wives or somehow managed to "exist and enjoy themselves on nothing at all." Coville also believed that Harbin's "excellent ballet dancers" and other performers were "trained in Moscow and smuggled out of Russia to Harbin" (all quotes from p. 235). 
The only difference was the presence of numerous Chinese shopkeepers, itinerant vendors, artisans and servants. But it was they who had to learn to speak Russian or, rather, the amusing Russo-Chinese pidgin called "Moya-tvoya," originated by Chinese peddlers in Siberia in the nineteenth century, which became the lingua franca for Russo-Chinese transactions in Harbin. ${ }^{6}$

Hinrichs does a fine job of demolishing the other misapprehension about Harbin: that it was culturally provincial. He cites statements to that effect by compilers of anthologies of Russian émigré poetry and a regrettably dismissive passage from the late Gleb Struve's indispensable Russkaia literatura $v$ izgnanii (1956). Harbin was an important cultural center from the first decade of its existence. The celebrated tenor Nikolai Figner and his Italian-born wife Medea sang there. When Leonid Andreev's first drama, $K$ zvezdam, was banned in St. Petersburg and Moscow, it pre-

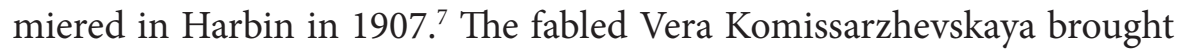

6 The exact proportion of Harbin's Russian-speaking population in comparison with the Chinese is hard to pinpoint. The section called Fudiedzian, inhabited only by the Chinese, where street names and shop signs were in their language, occupied approximately one-sixth of the city's area. But it was far more densely populated than any of the Russian sections.

For description and analysis of "Moya-tvoya," see the two articles on it by Johanna Nichols: "Pidginization and Foreigner Talk: Chinese Pidgin Russian," in Papers from the Fourth International Conference on Historical Linguistics, ed. Elizabeth Closs Traugott et al. (Amsterdam, 1980), 397-407; and "The Bottom Line: Chinese Russian," in Evidentiality: The Linguistic Coding of Epistemology, ed. Wallace Chafe and Johanna Nichols (Norwood, New Jersey, 1986), 239-57. Both articles cite earlier descriptions of "Moya-tvoya" and its occurrences in literary sources, especially in the writings of the ethnographer Vladimir Arseniev (1872-1930), whose book, V. Arsen'ev, Dersu Uzala, was turned by Akira Kurosawa into the film of the same name, made in the Soviet Union.

Since in Arseniev's books the Russo-Chinese pidgin is used by speakers of Tungusic languages (the central character in Dersu Uzala is a Nanai tribesman), Professor Nichols postulates a substratum in "Moya-tvoya" that comes from neither Russian nor Chinese but from Nanai. This would explain the reduplication of Russian words in such locutions as malo-malo (used instead of nemnogo or slegka), said to be a feature borrowed from Nanai. In the second of her cited articles, Professor Nichols proposes that "Moya-tvoya" "arose when the Russians and the Chinese began regular trading in 1768 in Kyakhta, located on the present Russian-Mongolian border south of Lake Baikal" (p. 240). [Included here is SK's corrected and expanded footnote for this article, to be found in carton 7 among his papers in the Bancroft Library, University of California, Berkeley, which remained unpublished.-Ed.]

7 See James B. Woodward, Leonid Andreyev: A Study (Oxford: Clarendon, 1969), 135. 
her company in 1909. During World War I, another major actress, Ekaterina Roshchina-Insarova, performed with an itinerant company of her own. Fyodor Chaliapin came in the 1930s to give several recitals and was lionized and feted at numerous banquets. Chaliapin did not sing with the Harbin Opera Company, as Hinrichs has it, but two singers of the Harbin opera were of a caliber to go on to international careers. The tenor Sergei Lemeshev went to the Soviet Union where he enjoyed great popularity. He made several Soviet films in the 1930s and was a guest star in the opera houses of Berlin and Prague in the late 1940s. The mezzo-soprano Irina Petina, noted in Harbin for her Carmen, eventually sang the same part at New York's Metropolitan Opera, appeared in Hollywood films (as "Irra Petina"), and had special parts composed for her by Leonard Bernstein (in Candide) and Heitor Villa-Lobos (in Magdalena).

Even apart from opera and theater, Harbin was a cultural city. The large number of Russian schools (most of which emphasized the study of Russian literature), periodicals, theaters (including such specialized ones as the highly popular theater of Ukrainian musical comedy and a company that performed only in Tatar), and libraries-all testify to the outstanding intellectual level of the multinational Harbin community. ${ }^{8}$ It was inevita-

8 An enormous amount of information about economic, cultural, medical, culinary, and numerous other aspects of life in Russian Harbin is found in Politekhnik, no. 10, a special tenth anniversary issue, 1969-79, Sydney, Australia. (I would like to thank my Berkeley colleagues and former fellow Harbiners, Boris Bressler and Gregory Grossman, for bringing this fascinating publication to my attention.) Ordinarily published as a newsletter by the graduates of the Harbin Polytechnic Institute who live in Australia, the anniversary issue of 1979 is a volume of 300 pages with some sixty articles and essays.

Among the highlights is an illustrated account of Harbin churches and temples. Besides the numerous Orthodox churches there were two large Jewish synagogues, a handsome mosque on the Artillereiskaia ulitsa, and Catholic, Protestant, and Old Believer churches. This article is followed by an eyewitness account of the demolition and burning during China's Cultural Revolution of the most beautiful and famous of Harbin churches, the St. Nicholas Cathedral, built in 1899 in the traditional Vologda style of wooden architecture. On 23 August 1966, Red Guards, for the most part hysterical teenagers, destroyed the cathedral and burned its priceless icons while beating drums and shouting Maoist slogans (Politekhnik, no. 10, 134-44).

Hinrichs cites in his annotations (132n14) two minor newsletters published in the West by former Harbin residents. He apparently did not have access to the two most substantial of such publications, Politekhnik in Sydney and the magazine-format Biulleten' of the "Igud Iotsei Sin," printed in Russian (with a brief supplement in English) in Tel Aviv. Biulleten' is now in its thirty-fifth year of publication. The latest edition avail- 
ble that a literature in Russian would arise in this atmosphere. ${ }^{9}$ There was no one of a stature comparable to that of Bunin or Tsvetaeva or Nabokov in Harbin. Novels and collections of stories were published in the 1920s and 1930s, but the only prose writers worthy of note were Nikolai Baikov, author of highly readable accounts of Manchuria, its nature and folklore, who also wrote works of fiction about the interaction of Russians with Manchuria's indigenous population (his first book on Manchuria was published in St. Petersburg in 1914; he died in Australia in 1958); and Boris Yulsky (Юльский), whose stories appeared in the illustrated weekly Rubezh and who died too young to have fulfilled his promise. ${ }^{10}$

Harbin's literary life manifested itself most intensely and memorably in poetry. An account of this poetry has now been written by the last still active Harbin poet, Valery Pereleshin (pen name of Valery Frantsevich Salatko-Petrishche, born in 1913 in Irkutsk), and edited with loving care by Jan Paul Hinrichs, a noted translator of exiled Russian poets into Dutch, who is also responsible for publishing the work of various other Russian writers in Holland. ${ }^{11}$ Hinrichs teaches at the University of Leiden and is the Slavic librarian of that university.

able at this writing (no. 298, June 1988) commemorates the fortieth anniversary of the arrival of some 6,000 Jewish residents of Manchuria and the rest of China in Israel. The issue features several memoirs about that event, including one by the magazine's editor, Boris Mirkin. There is also an installment of the posthumously published chronicle of the earliest period of Jewish presence in Harbin by A. I. Kaufman (see n. 13 below).

9 On the beginnings of Harbin's literary life, see Iu. (Iustina) Kruzenshtern-Peterets, "Churaevskii pitomnik: O dal'nevostochnykh poetakh," Vozrozhdenie (Paris), no. 204 (1968): 45-70. This article provides information on the period 1917-30, which antedates the time described in Pereleshin's memoirs. See also Mikhail Volin, "Russkie poety v Kitae," Kontinent (Paris), no. 34 (1982): 337-57.

10 For a biographical sketch of Baikov, see the special issue of Politekhnik cited in n. 8 above (181n6). It was depressing to learn from Pereleshin's memoirs that the talented Yulsky was a cocaine addict and a regular contributor to the Fascist newspaper Nash put'. Founded by the führer of the Russian Fascist movement Konstantin Rodzaevsky in 1932 and financed by the Japanese, this newspaper was the lowest example of gutter journalism that Harbin had ever seen. On Nash put' and the Russian Fascist movement in the Far East, see John J. Stephan, The Russian Fascists: Tragedy and Farce in Exile, 1925-1945 (New York, 1978).

11 See Europese Nacht: Vladislav Chodasevitsj, Georgij Ivanov, Boris Poplavskij, Gedichten, ed. and trans. Jan Paul Hinrichs (Maastricht, 1984); and Valerij Perelešin, Gedichten, ed. and trans. Jan Paul Hinrichs (Leiden, 1983). The latter has appeared in two more printings since its first publication, 1984 and 1985. Hinrichs is responsible for Dutch editions of, among others, Anna Akhmatova, Nikolai Gumilyov, and Vasily Rozanov. 
Pereleshin is a remarkable instance of a "twice-born" poet. He began publishing poetry at the very end of the 1920s in various Harbin periodicals. By the mid-1930s he was one of the best-known and most admired of Harbin poets. His first collection of verse appeared in 1937. Soon thereafter, he took monastic vows and departed first for Beijing, then for Shanghai. Three more collections of Pereleshin's poetry were published in Harbin between 1939 and 1944 by his mother, a well-known journalist. ${ }^{12}$

By leaving Harbin, Pereleshin escaped the fate of Russian poets who had remained there, such as Arseny Nesmelov (Несмелов; real surname: Mitropolsky [Митропольский]) and Aleksei Achair (Ачаир; real surname: Gryzov [Грызов]), who were deported to the gulags when Soviet troops occupied Harbin in August 1945. ${ }^{13}$ In 1950 Pereleshin tried to join his younger brother in California, but upon arriving in San Francisco he was imprisoned. An anonymous accuser had denounced him as a Soviet agent because, before giving up his monkhood, he had worked as a translator for the Soviet news agency TASS. Pereleshin was a rare example of a Russian writer in the Far East who took the trouble to study Chinese language and literature. His duties at TASS entailed nothing more than translating clippings from Chinese periodicals into Russian. But those were McCarthyite times and Pereleshin was deported back to China. From 1953 on, Pereleshin has lived in Rio de Janeiro. He is now a Brazilian citizen and considers himself a Brazilian poet who happens to write in Russian (though in 1983 he brought out a volume of his verse written in Portuguese).

Pereleshin's "second birth," to borrow Boris Pasternak's well-known phrase, took place when the last vestiges of Russian presence and culture

12 For a good thematic and technical analysis of Pereleshin's early collections of poetry, see Aleksis Rannit, "O poezii i poetike Valeriia Pereleshina: Shest' pervykh sbornikov poeta (1937-1971)," Russian Language Journal (East Lansing) 30 (Spring 1976): 79-104.

13 On the fate of Achair (the name has three syllables) and other poets after the Soviet invasion of Manchuria, see Valerii Pereleshin, "Konets Alekseia Achaira," Novoe russkoe slovo, 10 December 1972, 5. A shattering account of how various prominent members of the Harbin community, who had welcomed the Red Army as liberators from the Japanese, were invited by the Soviet command to receptions at which they were arrested and then deported, can be found in A. I. (Abram Iosifovich) Kaufman, Lagernyi vrach (Tel Aviv, 1973). Kaufman (1885-1971), a well-known Harbin physician, scholar, and Jewish civic leader, spent sixteen years in Soviet camps before he was allowed to join his family in Israel in 1961. 
had vanished in Manchuria and when Manchuria itself had ceased to exist as a separate entity-it now constitutes the four northeastern provinces of the People's Republic of China. From 1967 on, Pereleshin's poems and essays began to appear in Novoe russkoe slovo (New York), Novyi zhurnal (New York), Vozrozhdenie (Paris), and Grani (West Germany), thus breaking a quarter of a century of literary silence.

Since then, Pereleshin has published eight more collections of his verse including Iuzhnyi dom, a volume of poetry about the cultures of ancient and modern China and his involvement with them both; Kachel', a book of highly original metaphysical and religious poetry, which includes the long poem Poema o mirozdanii and the wreath of sonnets Krestnyi put'; and Ariel', astounding in its profundity, virtuosity, and thematic unconventionality. ${ }^{14}$ With these books, Pereleshin has outgrown in magnitude his Harbin contemporaries of the period 1930-50. He has by now become one of the four or five most important Russian poets of the second half of the twentieth century. He is also a diligent and resourceful translator of poetry. After his very moving rendition into Russian of $L i$ Sao, a long "politico-erotic elegy" written by the Chinese poet Ch'u Yuan ca. 300 BC, came his anthologies of Chinese and Brazilian poets in Russian and a Portuguese translation of Mikhail Kuzmin's Aleksandriiskie pesni. ${ }^{15}$

Yet, through it all, Pereleshin's literary beginnings in Harbin's congenial cultural environment have remained the center of his interest. During the decade of the 1970s he produced two major autobiographical texts: the memoirs under review, whose full title is Dva polustanka: Vospominaniia svidetelia i uchastnika literaturnoi zhizni Kharbina i Shankhaia (Two waystations: Memoirs of a witness to and participant in the literary life of

14 Valerii Pereleshin, Iuzhnyi dom (Munich, 1968); Kachel' (Frankfurt am Main, 1971); Ariel', with an introductory essay by Yury Ivask (Frankfurt am Main, 1976). On the metaphysical dimension in Kachel' and other poetry by Pereleshin, see Valentin Evdokimov (Moscow), "Chertovy kacheli' i sed'moe nebo" (the first half of the title refers to a well-known poem by Fyodor Sologub), Vestnik Russkogo khristianskogo dvizheniia (Paris), no. 139 (1983), 173-91. On Ariel', see Simon Karlinsky, "A Hidden Masterpiece: Valery Pereleshin's Ariel," Christopher Street 2, no. 6 (December 1977): 37-42 [included in the present volume].

15 Ch'u Yuan, Li Sao: Poema, trans. Valerii Pereleshin from the Chinese original (Frankfurt am Main, 1975); Stikhi na veere: Antologiia kitaiskoi klassicheskoi poezii (Frankfurt am Main, 1970); Iuzhnyi krest: Antologiia brazil'skoi poezii (Frankfurt am Main, 1978); M. Kuzmin, cotrans., Canticos de Alexandria (Rio de Janeiro, 1986). 
Harbin and Shanghai), and the long autobiographical poem, written in Onegin stanzas, Poema bez predmeta, six of whose eight cantos have been serialized in the literary journal Sovremennik. ${ }^{16}$

As the reader learns from both the memoirs and the narrative poem, Pereleshin matured as a poet through joining Churaevka, an association of younger Harbin writers founded by the older poet Aleksei Achair. What impresses one today about the young people who belonged to Churaevka is the breadth of their culture and the sureness of their literary choices. They knew the classics of Russian literature (any graduate of a Harbin high school did). They also knew the literature of early twentieth-century Modernism, which was at that time suppressed and withdrawn from circulation in the USSR. They were aware of what was going on in both the Soviet and the émigré literatures (individual issues of such émigré journals as Sovremennye zapiski or Chisla were regularly reviewed in the Harbin press). While the arbiters of taste in Russian Paris argued over whether Tsvetaeva had entered a period of decline or whether Sirin (Vladimir Nabokov) was a genuinely Russian writer or whether Boris Pasternak should be discarded for selling out to the Soviets, the young Harbin poets knew these writers' importance and applauded their achievements.

Harbin had no particular poetic school. Nesmelov's antecedents came from Russian Futurism and from Marina Tsvetaeva. Most of the Churaevka poets chose the Acmeist mold. Pereleshin's masters were Gumilyov and the Parisian heir of the Acmeists, Georgy Ivanov. Lidiya Khaindrova's model was Akhmatova, and Nikolai Shchyogolev's was Mandelstam. Harry (really Grigory) Satovsky-Rzhevsky, Jr., adored the poetry of Boris Poplavsky. Yet, these and other Harbin poets had poetic voices of their own. Pereleshin's memoirs resurrect names familiar to those interested in literature during the 1930s in Harbin: Marianna Kolosova, a poet of great vehemence, whose thematic monotony (she wrote of nothing but the horrors of Stalin's regime) makes some of her verse seem bathetic today; Larisa Andersen, equally gifted as poet, actress, and character dancer (who could ever forget her dance "Tabu," performed

16 The first six cantos of Pereleshin's Poema bez predmeta were serialized in the following issues of Sovremennik (Toronto): no. 35-36 (1977), 127-53; no. 37-38 (1978), 70-95; no. 39-40 (1978), 132-59; no. 41 (1979), 29-58; no. 42 (1979), 52-80; no. 45-46 (1980), 35-64. See n. 4 of the preceding essay. 
in a leopard skin to the music of Ernesto Lecuona at a kino-kontsert?), ${ }^{17}$ whose admirable poetry has stood the test of time quite well; and Nataliya Reznikova, whose once acclaimed novels, stories, and poems seem somewhat faded now.

Pereleshin is by no means an impartial chronicler. He draws a nasty caricature of Viktoriya Yankovskaya, whom I have always considered a rather interesting poet. His account of the visit to Harbin by the famed painter and stage designer Nikolai Roerich (1874-1947) is patently wrong. Roerich could not have been "almost one hundred years old" in the mid1930s and he could not have published "a book of his memoirs at the end of the last century," since he graduated from the St. Petersburg Art Academy in 1897. It was disappointing to find nothing about the well-wrought light verse of Aleksandra Parkau, even if we do get an anecdote about her unconventional domestic arrangements.

The book will put those who are familiar with Harbin literature in a nostalgic mood, as the readers of this review must have gathered by now. Those who know nothing of Harbin will be introduced to a fascinating and mostly unfamiliar chapter in the history of Russian culture. The second part of the memoirs traces the fate of several Harbin writers who moved to Shanghai at the end of the 1930s because the Japanese occupation of Manchuria made things uncomfortable and a Soviet invasion seemed imminent. There, in the international settlement and the French concession, they tried to continue the literary life they had known in Harbin. Volumes of poetry were published; Russian literary journals were started. But cosmopolitan Shanghai did not possess the Russian readership that had existed in Harbin. The triumph of Mao's revolution in 1949 spelled the end of all Russian culture in China.

17 Kino-kontserty were afternoon performances, usually on Saturdays, where before seeing the latest Marlene Dietrich or Shirley Temple film (a Shirley Temple fan club existed in Harbin in the 1930s) or one of the Ginger Rogers-Fred Astaire musical comedies, one could watch a live variety show. The latter could include performances by singers (Sofiya Redzhi, a Harbin precursor of Edith Piaf, with her pesni ulitsy or the more sedate Mariya Sadovskaya); the beloved comedian Fyodor Khmarin; one of the popular dance duos, such as the ballerina Olga Manzhelei and her husband Boris Serov; modest corps-de-ballet numbers; and, especially, exotic dancers, such as Larisa Andersen, Nina Antares, or Mara Vasilevskaya (one of whose dances, "Satanella," depicted a she-devil and was performed in a black satin evening gown of extremely complex cut with a pair of silver horns on her head). 
The publication of Pereleshin's memoirs in the Netherlands is one more signal of the current renewal of interest in Harbin both in the West and in the Soviet Union. The erstwhile Harbin and Shanghai resident Nataliya Ilina, now a Soviet writer, achieved considerable success with her semiautobiographical two-volume novel Vozvrashchenie. Pereleshin is quite right to point out that the novel slanders Harbin's Russian community. Ilina's more recent collection of autobiographical essays is still fairly slanderous but less so, while its currently serialized sequel is almost objective and contains an admiring section on Larisa Andersen. ${ }^{18}$ Ilina's great popularity indicates that Soviet readers are interested in learning about Harbin, now so distant both geographically and historically. In the West, the unexpected recent publication of Nesmelov's selected prose fiction $^{19}$ and Pereleshin's ceaseless efforts, expressed in numerous articles and essays and crowned by the appearance of his memoirs, suggest that there might be a comparable interest outside the Soviet Union. The following lines from Arseny Nesmelov's poem about the founding of Harbin, which was cited at the beginning of this review, may well turn out to be prophetic:

Milyi gorod, gord i stroen,

Budet den' takoi,

Chto ne vspomniat chto postroen

Russkoi ty rukoi.

Pust' udel podobnyi gorek,-

Ne opustim glaz:

Vspomiani, starik-istorik,

Vspomiani o nas. ${ }^{20}$

18 Compare Nataliia Il'ina, Dorogi i sud'by (Moscow, 1985), and the section "Larisa" in her "Vstrechi," Oktiabr', 1987, no. 5, 83-92.

19 Arsenii Nesmelov, Izbrannaia proza, ed. Emmanuil Shtein (Orange, CT, 1987).

20 "Dear city, proud and graceful, / There will come a day / When it won't be remembered / That you were built by a Russian hand // Though such a destiny be bitter,- / We will not lower our eyes: / Remember, aged historian, / Remember us."-Ed. 